\title{
RECESSION OF PREDOMINANTLY SANDY BLUFFS
}

Mahsa Ghazian Arabi, State University of New York at Stony Brook, mahsa.ghazianarabi@stonybrook.edu Ali Farhadzadeh, State University of New York at Stony Brook, ali.farhadzadeh@stonybrook.edu

Ali Khosravi, University of California, Davis, khali60@gmail.com

\section{INTRODUCTION}

Climate change and sea level rise are anticipated to accelerate coastal erosion, a major societal issue during the past half-century (Hapke, et al., 2009). While important progress has been made in predicting sandy beach responses to various ocean climates, a similar progress has not been made for coastal bluffs. Coastal bluff recession is a natural process that can become a hazard when it endangers buildings and developed properties (e.g., Figure.1). Despite some early works on cohesive shoreline erosion mechanisms (Dalrymple, et al., 1986; Sunamura, 1985), prediction of bluff recession still remains one of the main questions in coastal zone management. Several experiment studies were conducted in wave flumes to investigate the effective parameter. Earlier experiments focused mainly on hard cliff and cohesive bluffs erosion in the 1970s, under normally incident waves and have been reported by Sanders (1968), Horikawa and Sunamura (1970), and Sunamura (1983). During the 1980s-1990s a number of studies were conducted to understand erosion of cohesive coastal profiles with or without an overlying veneer of sand (Nairn, 1986, and Skafel and Bishop, 1994). These works used artificial or prototype clays for the cliff and focused primarily on the erosion process of the clay at beach or foreshore. A recent study by Caplain et al. (2011) investigates the effect of wave climate on the rate of sandy cliff recession in a wave flume. They reported observations of sand movements, sand bars dynamics and cliff recession rate.

The mechanism of cohesive shoreline erosion involves a combination of various morphodynamic and geotechnical parameters that need to be understood in order to be able to accurately predict recession rates. The purpose of present works is investigating the effect geotechnical parameters in recession rate of sandy bluffs.

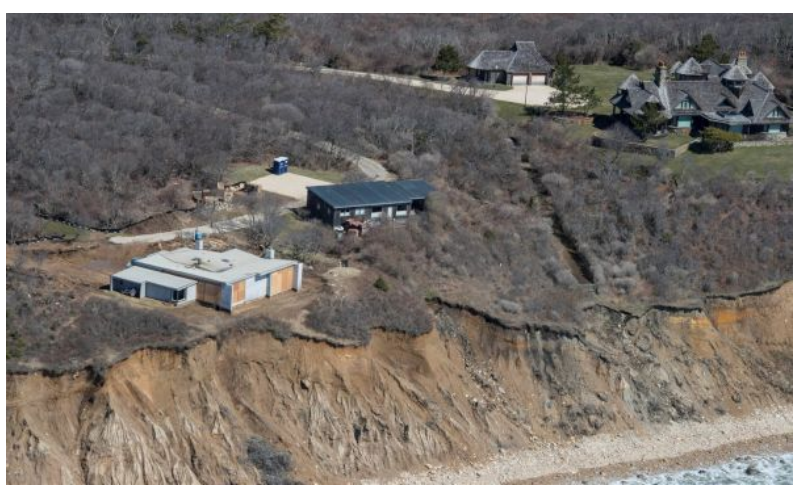

Figure 1. Bluffs, nearly vertical and actively eroding, Montauk, NY (Blidner, 2017, Newsday)

\section{METHODOLOGY}

This study aims at understanding recession processes for predominantly sandy bluff similar to those found near Montauk, on the south shore of Long Island, NY. Samples of bluff materials are taken from a number of sites. The material in the bluffs is sand along the north shore and sandy loam or loamy sand at Montauk Point. Several soil tests were performed to determine the primary properties of the sandy soil samples: grain size distribution test (ASTM D422), specific gravity of soils test (ASTM D854), plasticity index test (ASTM D4318). Figure 2 shows the particle gradation curve for one of the samples demonstrating $88 \%$ of the bluff materials is sand. The actual water content in the field was $10.5 \%$ and specific gravity of the sample is 2.55 . Sample categorized as Clayey Sands (SC) based on Unified Soil Classification System (USCS). A series of consolidated-undrained triaxial tests were performed on the sand under the same compaction conditions, and the peak friction angle and cohesion were found to be $33.4^{\circ}$ and $11 \mathrm{KPa}$, respectively.

To understand the mechanism of erosion in a predominantly sand coastal bluff, a series of laboratory experiments are conducted in a wave flume at Coastal and Hydraulic Engineering Research Laboratory at Stony Brook University. These tests are designed to quantify rates of erosion and recession of the bluffs for various geotechnical parameters, i.e. void ratio. The bluffs are tested under various waves and water level conditions. The bluff profiles are measured along with the hydrodynamic parameters, i.e., water level and velocity profile.

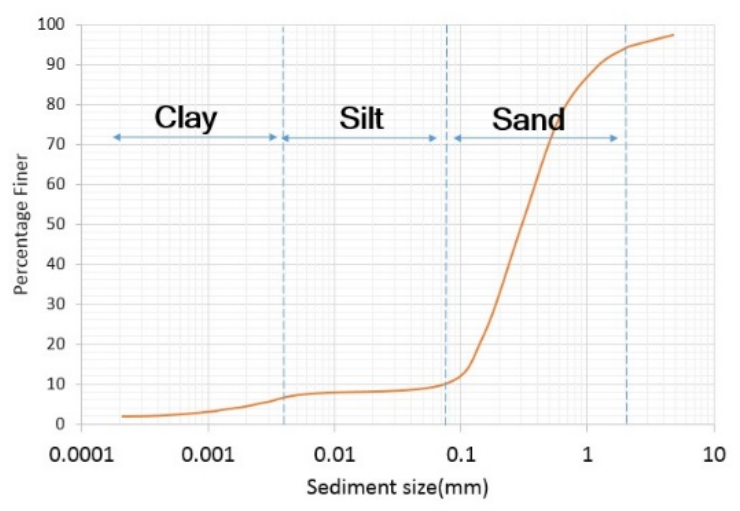

Figure 2. Soil Sample Gradation-Montauk Bluff

\section{DISCUSSION}

The relationship established between critical shear stresses and void ratio shows that the critical shear stress increases with the decrease of void ratio in the bluff material. The results are expected to lead to quantifying some of the underlying factors involved in the erosion of coastal bluffs. 
Early observations on responses of bluffs of given geotechnical properties to various wave and water level conditions are presented. This includes profile evolutions, mechanism of recessions and their rates etc.

\section{REFERENCES}

Hapke, Reid, Richmond, 2009. Rates and Trends of Coastal Change in California and the. Journal of Coastal Research, p. 603-615.

Caplain, B., Astruc, D., Regard, V., Moulin F. Y., 2011, Cliff retreat and sea bed morphology under monochromatic wave forcing: Experimental study, C. R. Geoscience, 343,471-477.

Dalrymple, Biggs, Dean, Wang, 1986. Bluff recession rates in Chesapeake Bay. J. Waterway, Port, Coastal, Ocean Eng, pp. 164-168.

Damgaard, J.S., Dong, P., 2004. Soft cliff recession under oblique waves: physical model tests. Journal of waterway, port, coastal and ocean engineering 130 (5), 234-242.

Horikawa, K., and Sunamura, T.,1970,. A study on erosion of coastal cliffs and submarine bedrocks. Coast. Eng. Japan, 13, 127-139.

Nairn, R. B., 1986. Physical modelling of wave erosion on cohesive profiles. Proc., Symp. Cohesive Shores, National Research Council, Canada, 210-225.

Sanders, N. K., 1968, 'Wave tank experiments on the erosion of rocky coasts. Pap. Proc. R. Soc. Tasmania, 102, 11-16.

Skafel, M. G., and Bishop, C. T., 1994. Flume experiments on the erosion of till shores by waves. Coastal Eng., 23, 329-348.

Sunamura, R., 1983. Processes of sea cliff and platform erosion. CRC handbook of coastal processes and erosion, P. D. Komar, ed., Chemical Rubber Corp., Boca Raton, Fla., 233-265.

Sunamura, 1985. A simple relationship for predicting wave height in the surf zone with a uniformly sloping bottom. Transactions of the Japanese Geomorphological Union 64, pp. 361-364. 